\title{
Impact of TEI (Trait Emotional Intelligence) on Adaptability of Gen Z Management Students
}

\author{
D. Ravindran ${ }^{1 *}$, C. Anita ${ }^{2}$ and B. Arul Senthil ${ }^{3}$ \\ 'Assistant Professor, School of Management, Kristu Jayanti College (Autonomous), Bengaluru, Karnataka, India; \\ rtkob@yahoo.co.in \\ ${ }^{2}$ Assistant Professor, Department of Computer Science, Kristu Jayanti College (Autonomous), Bengaluru, Karnataka, \\ India; anita@kristujayanti.com \\ ${ }^{3}$ Assistant Professor, Department of MBA, ABBS, Bangalore - 560091, Karnataka, India; \\ arulsenthilphd@gmail.com
}

\begin{abstract}
There has been so much study undertaken worldwide about the positive impact of the emotional intelligence of a person. This study investigated the impact of trait emotional intelligence profile on the adaptability of $141 \mathrm{Gen} \mathrm{Z}$ management students in Bangalore. Using the trait emotional intelligence questionnaire it was hypothesized that there is a strong correlation between adaptability of students and their trait EI.
\end{abstract}

Keywords: Adaptability, Gen Z, Trait Emotional Intelligence Questionnaire

\section{Introduction}

Ever since the emergence of the concept of emotional intelligence much has been studied about the topic and worldwide research had highlighted the positive impact of high emotional intelligence on the individuals' personal and professional well being. Among the currently available three models of emotional intelligence namely, the ability model, mixed model, and the trait model, the trait model looks into the individuals own perception of their emotional abilities. The study was conducted in Bangalore, the capital city of Karnataka. Factors such as being the IT capital of the country, the city with the highest number of colleges, affordability, good start-up ecosystem, yearlong good weather and its cosmopolitan culture had made Bangalore a much sort after city to pursue higher education. Most of the Business Schools have a mixture of students from different cultural backgrounds across India. Many a students pursue their post-graduation after gaining some work experience. A good number students pursuing higher education in the colleges in Bangalore is from non Karnataka states. The academic success and future career prospectives of the student to a great extend is dependent on the adaptability of the student. The study group choosenbelongs to Gen Z.

\section{Review of Literature}

Emotional intelligence is the ability to monitor one's own emotions, consciously regulate emotions once they are recognized, identify and interpret the emotions of others, and respond to all emotional cues in an appropriate manner (Mayer \& Salovey, 1997). Trait emotional intelligence (trait EI) refers to a collection of emotional self-perceptions located at the lower levels of personality hierarchies. (Petrides, Pita \& Kokkinaki, 2007). The trait EI construct provides a comprehensive operationalization of the

${ }^{*}$ Author for correspondence 
affect-related aspects of personality namely well being, emotionality, self control, sociability and adaptability which lies wholly outside the taxonomy of human cognitive ability (Carroll, 1993). As per the trait model individual has self perception of one's emotional abilities and can utilise these perceptions for good interaction with others. (Petrides \& Kokkinaki, 2007). The research related to emotional intelligence has been split into the perspectives of emotional competencies and their measurement (Mikolajczak, Luminet, \& Menil, 2006), ability models (Mayer \& Salovey, 1997) and the trait EI construct having 13-15 emotion-based behavioral dispositions influencing an individual under stressful and demanding situations. The trait test tires to capture the typical performance of an individual (Petrides \& Furnham, 2003).

There has been considerable literature on the age range of Gen Z. Generation Z refers to the people born after 1995. (Cilliers, 2017). This research subject aims at obtaining an answer for the following question of whether TEI score is influencing the adaptability of Gen ZMS in addition to self-motivation, self-orientation, stress handling and emotional well being.

Self-motivation is an individual's ability to do what needs to be done, without influence from other people or situations. People with self-motivation tends to find a reason and strength to complete a task, overcoming challenges, without giving up or without external encouragement. Studies show that people with high EQ tend to have a higher level of emotional well being. (Salovey and Mayer, 1990). Students with high emotional intelligence tend to be more self-motivated with a high level of self-efficacy. (Gharetepeh, A., Safari, Y., Pashaei, T., Razaei, M., and Bagher Kajbaf, M.2015). People with high EQ tend to cope up well with stress. (Ramesar, S., Koortzen, P., and Oosthuizen, R.M. 2009). Being adjust to new situations is high in individuals with high emotional intelligence. (Sony, Michael and Mekoth, Nandakumar, 2016). Studies have shown that higher-performing employees are more adaptable (Cullen, Edwards, Casper, and Gue, 2014). The family background and the interaction with the members of a family play a pivotal role in the emotional development of an individual. Students belonging tojoint families were emotionally more stable than the ones belonging to nuclear families. (Singh, Ritu and Pant, Kusha and Laitonjam, Valentina
2014) divergent views have been brought in about the correlation of emotional intelligence and the place of origin of an individual. The upbringing is affected by the locality. However, it is generally concluded that there has been no significant correlation between emotional intelligence between the city and rural students. (Khan, Mahmood and Lone, Mohammad Muzzafar. 2015). Individuals from nontechnical educational background tends to have more emotional intelligence than the ones who have technical academic qualifications and emotional intelligence tends to increase with age. (Pooja, Pooja and Kumar, Pranab. 2016). Entrepreneurial aspirations are high in Gen $\mathrm{Z}$ and there is a high correlation between entrepreneurship and emotional intelligence. (H Fakhr Eldn. 2017). An adaptable individual is able to handle better the uncertainty and stress in workplace and can accommodate well with different geographical relocations of a work environment (Pearlman and Barney, 1998).

\section{Objectives of the Research}

- The objective of the research is to assess the impact of trait EI on the adaptability of Gen Z management students in Bangalore.

- To establish the various factors affecting the triat EI of the students their by influencing the adaptability of the Gen $\mathrm{Z}$ management students.

\section{Hypotheses}

H1: There is a significant correlation between student's adaptability and other trait EI factors.

$\mathrm{H} 2$ : There exists a significant difference between the trait EI factors and demographic profile of the students with respect to adaptability.

H3: There exists a strong correlation between the trait EI factors and family size of the students with respect to adaptability.

\section{Limitations}

The study was conducted only with respect to students from Bangalore wherein the sample population is from only two colleges in the city. Samples could be taken 
from the selected colleges in Bangalore or samples from different cosmopolitian cities can be considered. The period of study is also limited to one month (Dec 2019). The respondents were considered only from students pursuing management studies in their higher education. As the demographic profile of Bangalore students is diverse the results cannot be substantiated solely as an indicator of Bangalore.

\section{Research Methodology}

A descriptive research design is adopted in this research. The sample size is 141 and selected using a convenience sampling method.

\subsection{Data Collection}

\subsubsection{Primary Data}

The data were collected by using questionnaire circulated among MBA students in Bangalore, through google forms shared with the students in class after explaining the purpose and the contents in the questionnaire.

\subsubsection{Secondary Data}

Other secondary data were collected from journals, websites, discussions with students, teachers and other online sources.

\section{Proposed Model}

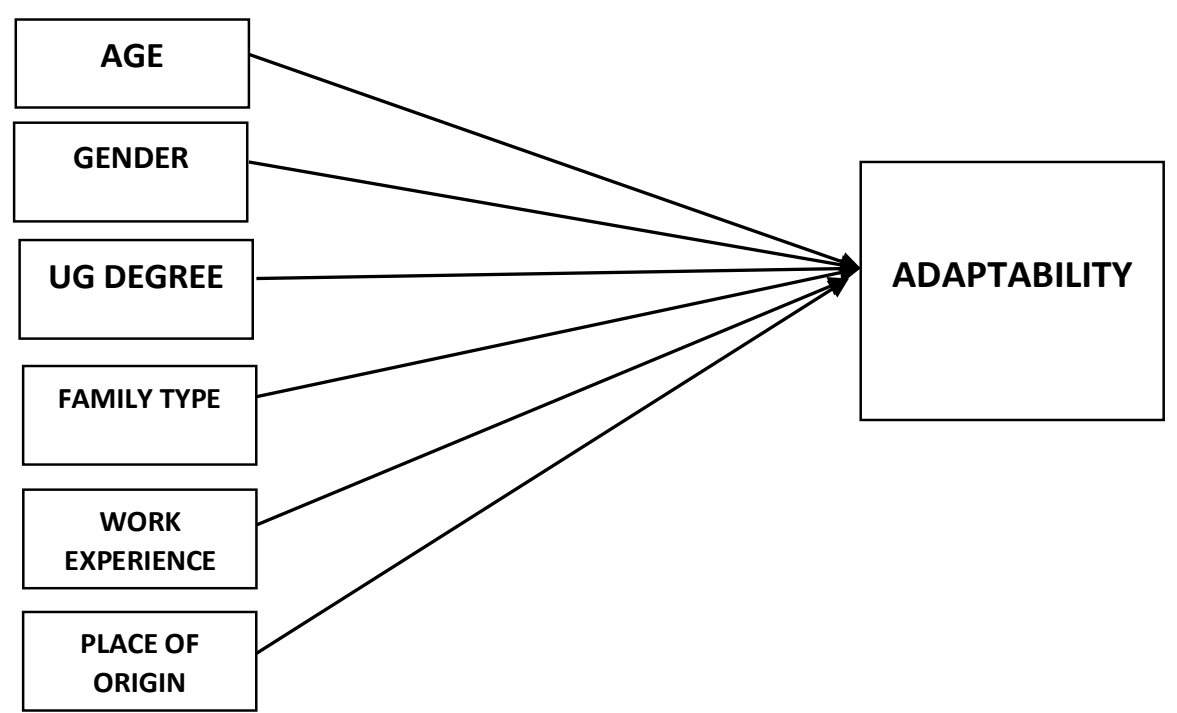

The proposed model for the research is stated in the above figure.

\section{Data Analysis and Interpretation}

\subsection{Descriptive Statistics-frequency Table}

\begin{tabular}{|c|c|c|c|}
\hline Details & Options & Frequency & Percentage \\
\hline \multirow{2}{*}{ Age in years } & $20-25$ & 140 & 99.29 \\
\cline { 2 - 4 } & $26-28$ & 1 & 00.71 \\
\hline & Total & 141 & 100.0 \\
\hline
\end{tabular}




\begin{tabular}{|c|c|c|c|}
\hline \multirow{2}{*}{ Gender } & Male & 80 & 56.7 \\
\hline & Female & 61 & 43.3 \\
\hline & Total & 141 & 100.0 \\
\hline \multirow{3}{*}{ UG Degree } & Arts and Science & 126 & 89.4 \\
\hline & Engineering & 15 & 10.6 \\
\hline & Total & 141 & 100.0 \\
\hline \multirow{3}{*}{ Family Type } & Nuclear & 117 & 83.0 \\
\hline & Joint Family & 24 & 17.0 \\
\hline & Total & 141 & 100.0 \\
\hline \multirow{4}{*}{ Work Experience } & No Work Exp & 117 & 83.0 \\
\hline & $0.1-1 \mathrm{yr}$ & 14 & 9.9 \\
\hline & $1.1-2 \mathrm{yr}$ & 10 & 7.1 \\
\hline & Total & 141 & 100.0 \\
\hline \multirow{4}{*}{ Place of origin } & Urban(Metro Cities) & 44 & 31.2 \\
\hline & $\begin{array}{c}\text { Semi Urban (Other developed } \\
\text { cities) }\end{array}$ & 50 & 35.5 \\
\hline & Rural (Village/Panchayats) & 47 & 33.3 \\
\hline & Total & 141 & 100.0 \\
\hline
\end{tabular}

\subsection{Factor Analysis - Found Six Factors}

\begin{tabular}{|c|c|c|}
\hline \multicolumn{3}{|c|}{ KMO and Bartlett's Test } \\
\hline \multicolumn{2}{|c|}{ Kaiser-Meyer-Olkin Measure of Sampling Adequacy. } & .894 \\
\hline \multirow{2}{*}{ Bartlett's Test of Sphericity } & Approx. Chi-Square & 2714.145 \\
\cline { 2 - 3 } & Df & 435 \\
\cline { 2 - 3 } & Sig. & .000 \\
\hline
\end{tabular}




\begin{tabular}{|c|c|c|c|c|c|c|c|c|c|}
\hline \multicolumn{10}{|c|}{ Total Variance Explained } \\
\hline \multirow{2}{*}{ Component } & \multicolumn{3}{|c|}{ Initial Eigenvalues } & \multicolumn{3}{|c|}{$\begin{array}{c}\text { Extraction Sums of Squared } \\
\text { Loadings }\end{array}$} & \multicolumn{3}{|c|}{$\begin{array}{c}\text { Rotation Sums of Squared } \\
\text { Loadings }\end{array}$} \\
\hline & Total & $\begin{array}{c}\% \text { of } \\
\text { Variance }\end{array}$ & $\begin{array}{c}\text { Cumulative } \\
\%\end{array}$ & Total & $\begin{array}{c}\% \text { of } \\
\text { Variance }\end{array}$ & $\begin{array}{c}\text { Cumulative } \\
\%\end{array}$ & Total & $\begin{array}{c}\% \text { of } \\
\text { Variance }\end{array}$ & $\begin{array}{c}\text { Cumulative } \\
\%\end{array}$ \\
\hline 1 & 11.393 & 37.975 & 37.975 & 11.393 & 37.975 & 37.975 & 6.722 & 22.406 & 22.406 \\
\hline 2 & 3.837 & 12.789 & 50.764 & 3.837 & 12.789 & 50.764 & 3.696 & 12.319 & 34.725 \\
\hline 3 & 1.624 & 5.412 & 56.177 & 1.624 & 5.412 & 56.177 & 3.232 & 10.772 & 45.497 \\
\hline 4 & 1.193 & 3.975 & 60.152 & 1.193 & 3.975 & 60.152 & 2.435 & 8.115 & 53.612 \\
\hline 5 & 1.104 & 3.679 & 63.83 & 1.104 & 3.679 & 63.83 & 2.295 & 7.651 & 61.263 \\
\hline 6 & 1.032 & 3.439 & 67.27 & 1.032 & 3.439 & 67.27 & 1.802 & 6.007 & 67.27 \\
\hline 7 & 0.913 & 3.044 & 70.313 & & & & & & \\
\hline 8 & 0.824 & 2.747 & 73.06 & & & & & & \\
\hline 9 & 0.798 & 2.659 & 75.719 & & & & & & \\
\hline 10 & 0.668 & 2.226 & 77.945 & & & & & & \\
\hline 11 & 0.648 & 2.159 & 80.104 & & & & & & \\
\hline 12 & 0.571 & 1.902 & 82.006 & & & & & & \\
\hline 13 & 0.557 & 1.857 & 83.863 & & & & & & \\
\hline 14 & 0.536 & 1.786 & 85.649 & & & & & & \\
\hline 15 & 0.47 & 1.567 & 87.216 & & & & & & \\
\hline 16 & 0.446 & 1.486 & 88.702 & & & & & & \\
\hline 17 & 0.404 & 1.347 & 90.049 & & & & & & \\
\hline 18 & 0.392 & 1.308 & 91.356 & & & & & & \\
\hline 19 & 0.342 & 1.141 & 92.497 & & & & & & \\
\hline
\end{tabular}




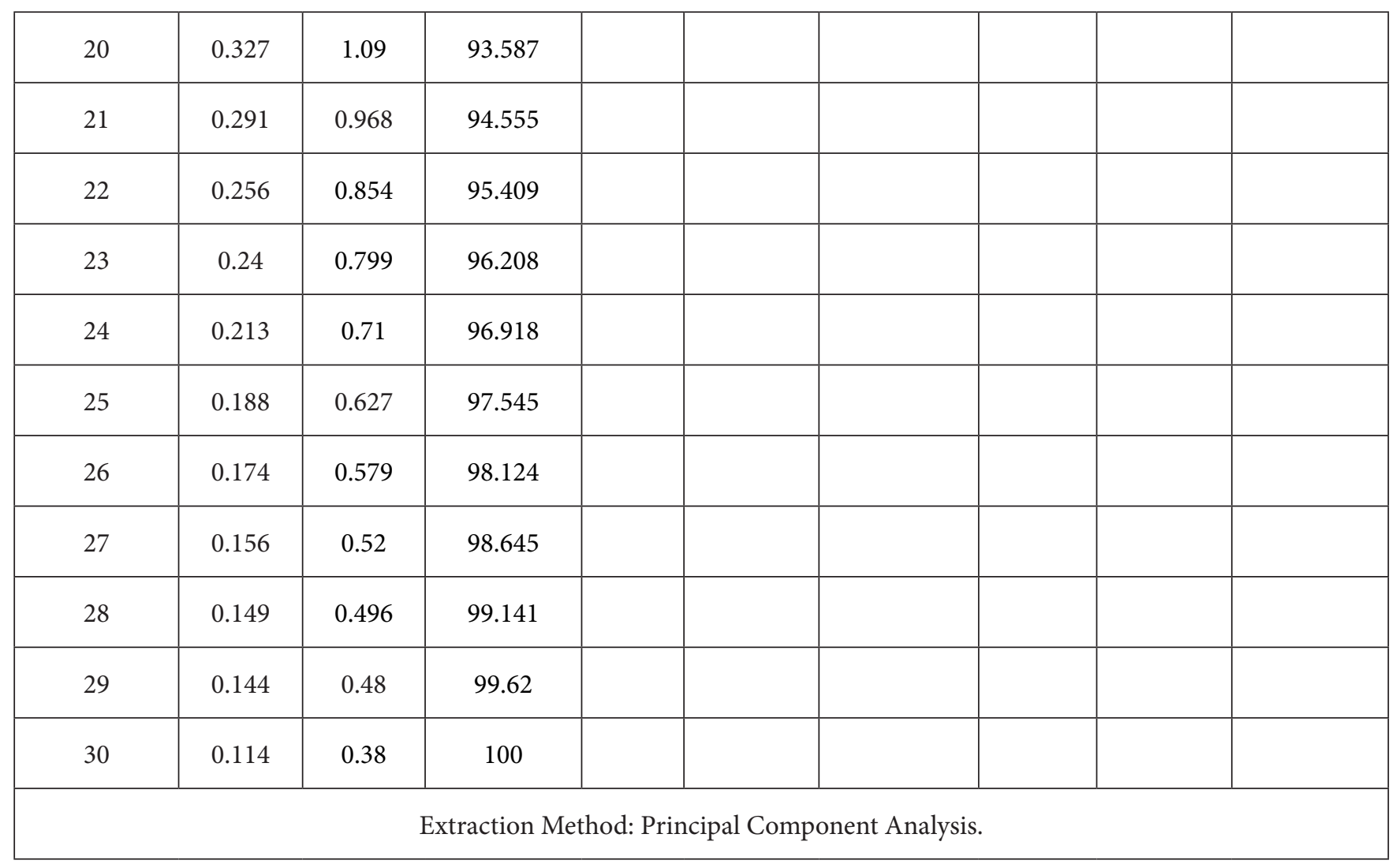

\begin{tabular}{|c|c|c|c|c|c|c|}
\hline \multicolumn{7}{|c|}{ Rotated Component Matrix ${ }^{\mathrm{a}}$} \\
\hline & \multicolumn{6}{|c|}{ Component } \\
\hline & 1 & 2 & 3 & 4 & 5 & 6 \\
\hline $\begin{array}{l}\text { I can deal effectively with } \\
\text { people }\end{array}$ & .829 & & & & & \\
\hline $\begin{array}{l}\text { I feel that I have a number of } \\
\text { good qualities }\end{array}$ & .816 & & & & & \\
\hline $\begin{array}{l}\text { Expressing my emotions with } \\
\text { words is not a problem for me. }\end{array}$ & .783 & & & & & \\
\hline $\begin{array}{l}\text { On the whole, I'm a highly } \\
\text { motivated person }\end{array}$ & .734 & & & & & \\
\hline $\begin{array}{l}\text { I believe I'm full of personal } \\
\text { strengths. }\end{array}$ & .680 & & & & & \\
\hline $\begin{array}{l}\text { I would describe myself as a } \\
\text { good negotiator. }\end{array}$ & .654 & & & & & \\
\hline $\begin{array}{l}\text { I often find it difficult to show } \\
\text { my affection to those close to } \\
\text { me. }\end{array}$ & .654 & & & & & \\
\hline
\end{tabular}




\begin{tabular}{|c|c|c|c|c|c|c|}
\hline $\begin{array}{l}\text { I'm usually able to find ways to } \\
\text { control my emotions when I } \\
\text { want to. }\end{array}$ & .624 & & & & & \\
\hline $\begin{array}{l}\text { On the whole, I'm pleased with } \\
\text { my life. }\end{array}$ & .606 & & & & & \\
\hline $\begin{array}{l}\text { I'm usually able to influence the } \\
\text { way other people feel }\end{array}$ & .599 & & & & & \\
\hline $\begin{array}{l}\text { I often pause and think about } \\
\text { my feelings }\end{array}$ & & .732 & & & & \\
\hline $\begin{array}{l}\text { I tend to change my mind } \\
\text { frequently }\end{array}$ & & .689 & & & & \\
\hline $\begin{array}{l}\text { On the whole, I have a gloomy } \\
\text { perspective on most things. }\end{array}$ & & .688 & & & & \\
\hline $\begin{array}{l}\text { I find it difficult to bond well } \\
\text { even with those close to me. }\end{array}$ & & .672 & & & & \\
\hline $\begin{array}{l}\text { I generally don't find life } \\
\text { enjoyable }\end{array}$ & & .640 & & & & \\
\hline $\begin{array}{l}\text { I tend to "back down" even if I } \\
\text { know I'm right. }\end{array}$ & & .623 & & & & \\
\hline $\begin{array}{l}\text { I often find it difficult to see } \\
\text { things from another person's } \\
\text { viewpoint. }\end{array}$ & & .621 & & & & \\
\hline $\begin{array}{l}\text { I tend to get involved in things } \\
\text { I later wish I could get out of. }\end{array}$ & & & .769 & & & \\
\hline $\begin{array}{l}\text { I don't seem to have any } \\
\text { power at all over other people's } \\
\text { feelings. }\end{array}$ & & & .671 & & & \\
\hline $\begin{array}{l}\text { Others admire me for being } \\
\text { relaxed. }\end{array}$ & & & .602 & & & \\
\hline $\begin{array}{c}\text { Generally, I'm able to adapt to } \\
\text { new environments. }\end{array}$ & & & .588 & & & \\
\hline $\begin{array}{c}\text { On the whole, I'm able to deal } \\
\text { with stress }\end{array}$ & & & & .859 & & \\
\hline $\begin{array}{c}\text { Those close to me often } \\
\text { complain that I don't treat them } \\
\text { right. }\end{array}$ & & & & .746 & & \\
\hline $\begin{array}{l}\text { I often find it difficult to } \\
\text { adjust my life according to the } \\
\text { circumstances }\end{array}$ & & & & .625 & & \\
\hline $\begin{array}{l}\text { I normally find it difficult to } \\
\text { keep myself motivated. }\end{array}$ & & & & .436 & & \\
\hline $\begin{array}{l}\text { I generally believe that things } \\
\text { will work out fine in my life. }\end{array}$ & & & & & .704 & \\
\hline
\end{tabular}




\begin{tabular}{|c|l|l|l|l|l|l|}
\hline $\begin{array}{c}\text { I'm normally able to "get } \\
\text { into someone's shoes" and } \\
\text { experience their emotions }\end{array}$ & & & & & .630 & \\
\hline $\begin{array}{c}\text { I usually find it difficult to } \\
\text { regulate my emotions }\end{array}$ & & & & & & .634 \\
\hline $\begin{array}{c}\text { Many times, I can't figure out } \\
\text { what emotion I'm feeling }\end{array}$ & & & & & & .555 \\
\hline $\begin{array}{c}\text { I often find it difficult to stand } \\
\text { up for my rights }\end{array}$ & & & & & & \\
\hline $\begin{array}{r}\text { Extraction Method: Principal Component Analysis. } \\
\text { Rotation Method: Varimax with Kaiser Normalization. }\end{array}$ \\
\hline \\
a. Rotation converged in 9 iterations. \\
\hline
\end{tabular}

\subsection{Mean Score Analysis}

\begin{tabular}{|c|c|c|c|c|c|}
\hline \multicolumn{7}{|c|}{ Descriptive Statistics } \\
\hline Factors Identified & $\mathrm{N}$ & Minimum & Maximum & Mean & Std. Deviation \\
\hline Selfmotivated & 141 & 1.00 & 7.00 & 4.4844 & 1.39316 \\
\hline Selforiented & 141 & 1.00 & 7.00 & 3.7447 & 1.25911 \\
\hline Adaptability & 141 & 1.00 & 7.00 & 4.3475 & 1.53086 \\
\hline Stressful & 141 & 1.00 & 7.00 & 3.4025 & 1.66207 \\
\hline Sociability & 141 & 1.00 & 7.00 & 4.6631 & 1.48751 \\
\hline
\end{tabular}

\section{Inference:}

Among the tait EI factors, Sociability (4.6631) was found to be having more influence. High mean score says more influence. Sociabillity (4.6631) is followed by Self-motivation (4.4844) and Adaptability (4.3475). The other factors Self-orientation, Stressful and Emotionalilty characteristics were found to be having moderate influence on the Emotional intelligence of management students. 


\subsection{Correlation Analysis between Adaptability and other EI traits}

\section{Inference:}

Among the five EI traits, Self motivation recorded a higher positive correlation (.652) followed by Social orientation
(.624) with Adaptability.

Self orientation (.575) have a moderate positive correlation and the remaining traits Stressful (.424) and Emotionality (.426) have lesser positive correlation with Adaptability.

\begin{tabular}{|c|c|c|c|c|c|c|c|}
\hline \multicolumn{7}{|c|}{ Correlation Analysis with Adaptability with other EI Traits } \\
\hline & $\begin{array}{c}\text { Self } \\
\text { Motivated }\end{array}$ & $\begin{array}{c}\text { Self } \\
\text { Oriented }\end{array}$ & Adaptability & Stress Ful & Socialbility & Emotionality \\
\hline \multirow{7}{*}{ Adaptability } & $\begin{array}{c}\text { Pearson } \\
\text { Correlation }\end{array}$ &. $\mathbf{6 5 2}^{* *}$ & $.575^{* *}$ & 1 & $.424^{* *}$ &. $\mathbf{6 2 4 ^ { * * }}$ & $.426^{* *}$ \\
\cline { 2 - 8 } & $\begin{array}{c}\text { Sig. } \\
(2-\text {-tailed })\end{array}$ & .000 & .000 & & .000 & .000 & .000 \\
\cline { 2 - 8 } & $\mathrm{N}$ & 141 & 141 & 141 & 141 & 141 & 141 \\
\hline
\end{tabular}

\subsection{ANOVA with EI Factors and Age,} Qualification, Work Experience and Place of Origin

\section{Inference:}

There exists a significant difference only between the adaptability factor of emotional intelligence with place of origin of management students. The place of origin [Rural or Urban ] is influencing the adaptability of Gen Z management students.

\begin{tabular}{|c|c|c|c|c|}
\hline Factors & Age & Qualification & Experience & Place of Origin \\
\hline Selfmotivated & $\begin{array}{c}F(.264) \\
\text { Sig. }(.608)\end{array}$ & $\begin{array}{l}\mathrm{F}(3.482) \\
\text { Sig }(.064)\end{array}$ & $\begin{array}{c}F(.220) \\
\operatorname{Sig}(.803)\end{array}$ & $\begin{array}{l}F(1.863) \\
\text { Sig }(.159)\end{array}$ \\
\hline Selforiented & $\begin{array}{l}\mathrm{F}(1.101) \\
\operatorname{Sig}(.296)\end{array}$ & $\begin{array}{c}\mathrm{F}(.120) \\
\text { Sig }(.730)\end{array}$ & $\begin{array}{c}\mathrm{F}(.715) \\
\operatorname{Sig}(.491)\end{array}$ & $\begin{array}{c}\mathrm{F}(.092) \\
\text { Sig }(.913)\end{array}$ \\
\hline Adaptability & $\begin{array}{c}F(.165) \\
\text { Sig }(.685)\end{array}$ & $\begin{array}{l}\mathrm{F}(1.154) \\
\operatorname{Sig}(.285)\end{array}$ & $\begin{array}{l}F(1.002) \\
\operatorname{Sig}(.370)\end{array}$ & $\begin{array}{c}F(3.516) \\
\text { Sig }(.032)^{\star *}\end{array}$ \\
\hline Stressful & $\begin{array}{c}F(.569) \\
\text { Sig }(.452)\end{array}$ & $\begin{array}{l}F(1.699) \\
\text { Sig (.195) }\end{array}$ & $\begin{array}{c}\text { F (.918) } \\
\text { Sig }(.402)\end{array}$ & $\begin{array}{c}\text { F (.678) } \\
\text { Sig (.509) }\end{array}$ \\
\hline Sociability & $\begin{array}{c}\text { F (.650) } \\
\text { Sig }(.422)\end{array}$ & $\begin{array}{l}\mathrm{F}(3.355) \\
\text { Sig }(.069)\end{array}$ & $\begin{array}{c}\mathrm{F}(.235) \\
\operatorname{Sig}(.791)\end{array}$ & $\begin{array}{l}\mathrm{F}(1.145) \\
\operatorname{Sig}(.321)\end{array}$ \\
\hline Emotionality & $\begin{array}{l}\mathrm{F}(2.053) \\
\text { Sig }(.154)\end{array}$ & $\begin{array}{l}F(2.810) \\
\text { Sig }(.096)\end{array}$ & $\begin{array}{l}\mathrm{F}(1.034) \\
\text { Sig }(.358)\end{array}$ & $\begin{array}{l}\mathrm{F}(2.412) \\
\text { Sig }(.093)\end{array}$ \\
\hline
\end{tabular}


There exists no significant influence on adaptability by other trait EI factors.

\subsection{Independent Sample T Test (EI Factors and Gender and Family Type)}

\section{Inference:}

There exists no significant difference between the EI factors (Self motivated, Self oriented, Adaptability, Stressssful, Social oriented and Emotionality characteristics) with respect to male and female management students. Gender is not an influencing factor in the adaptability of Gen $\mathrm{Z}$ management students.

There exists a significant difference between the selected EI factors (Self-motivated, Adaptability, Emotionality) with respect to management students from nuclear and joint family. The family type is influencing the adaptability of Gen $\mathrm{Z}$ management students.
Keeping in mind the results, the students can be motivated towards jobs which require multitasking, spanning across geographical boundaries and working with people from different ethnic backgrounds. The study suggests that students can be given orientation and suggestions regarding the future career roles. Gen $\mathrm{Z}$ is positively driving entrepreneurship and sufficient training on this aspect can be included in the courses offered during their education. The online learning market is lead by Gen $\mathrm{Z}$ shows that they are self motivated and self driven and are willing to explore and learn new things when compared to the previous generations. Since there is a good difference between the adaptability of students from diverse family background, more experiential learning activities involving group work can be introduced during the course of study. Extra care can be taken by the are not influenced by the variables [age, gender, qualification, and work experience].

\begin{tabular}{|c|c|c|}
\hline Factors & Gender & Family Type \\
\hline Selfmotivated & $\mathrm{F}(0.661), \operatorname{Sig}(.564)$ & $\mathrm{F}(0.5996), \operatorname{Sig}(.012)^{\star *}$ \\
\hline Selforiented & $\mathrm{F}(0.774), \operatorname{Sig}(.578)$ & $\mathrm{F}(2.837), \operatorname{Sig}(.36)$ \\
\hline Adaptability & $\mathrm{F}(0.176), \operatorname{Sig}(.284)$ & $\mathrm{F}(2.107), \operatorname{Sig}(.035)^{\star *}$ \\
\hline Stressful & $\mathrm{F} 0.384), \operatorname{Sig}(.917)$ & $\mathrm{F}(0.235), \operatorname{Sig}(.781)$ \\
\hline Socialoriented & $\mathrm{F}(0.857), \operatorname{Sig}(.681)$ & $\mathrm{F}(9.452), \operatorname{Sig}(.037)^{\star *}$ \\
\hline Emotionality & $\mathrm{F}(0.445), \operatorname{Sig}(.506)$ & $\mathrm{F}(0.212), \operatorname{Sig}(.004)^{\star *}$ \\
\hline
\end{tabular}

\section{Results and Discussion (Findings and Suggestions)}

Adaptability is an individual's quality. This study is confirming with the earlier studies pointing at good adaptability of Gen Z (Agarwal, Hemlata and Vaghela, Pratiksinh. 2018). Our study is indicating that the family type and the place of origin is influencing the adaptability of Gen Z Management students. The other trait EI factors is not influences by the variables (age, gender, qualification and work experience).
Keeping in mind the results, the students can be motivated towards jobs that require multitasking, spanning across geographical boundaries, and working with people from different ethnic backgrounds. The study suggests that students can be given orientation and suggestions regarding future career roles. Gen $\mathrm{Z}$ is positively driving entrepreneurship and sufficient training on this aspect can be included in the courses offered during their education. The online learning market is led by Gen $\mathrm{Z}$ shows that they are self-motivated and selfdriven and are willing to explore and learn new things 
when compared to the previous generations. Since there is a good difference between the adaptability of students from diverse family backgrounds, more experiential learning activities involving group work can be introduced during the course of study. Extra care can be taken by the educators at the beginning of the course of study itself to have knowledge about the family background and place of origin of students to have a better understanding of their behaviour in different curricular and co-curricular activities.

\section{Conclusion}

This study reveals the impact of trait EI on adaptiveness of students. This can suggest to positive interventions that can be carried out during or prior to the course of study of management education. This can help the teachers/ counsellors reinforce the positive attributes and explore the possibility of helping the ones with a less trait EI score. Special attention has to be provided to students whose place of origin is rural in terms of academic and emotional mentoring as it can help them to adjust to the urban educational environment.

\section{Scope for Future Research}

In future the study can be extended to students of other faculties. The impact of work experience prior to pursuing a master's programme can be explored. The impact of qualifying academic degree and adaptiveness can be explored in future studies. The validity of the predication can be substantiated if the sample population is studied for a longer duration to assess their well being in actual working environment.

\section{References}

Agarwal, H., \& Pratiksinh, V. (2018). Work Values of GEN Z: Bridging the Gap to the Next Generation..

Carroll, J. B. (1993). Human cognitive abilities: A survey of factor analytic studies. New York: Cambridge University Press, https://doi.org/10.1017/CBO9780511571312.

Cilliers, E. J. (2017). The challenge of teaching generation $\mathrm{Z}$. PEOPLE: International Journal of Social Sciences, 3(1), 188-198.
Cullen, K., Edwards, B., Casper, W., \& Gue, K. (2014). Employees' adaptability and perceptions of changerelated uncertainty: Implications for perceived organizational support, job satisfaction and performance. Journal of Business and Psychology, 29,269-280. https://doi.org/10.1007/s10869-013-9312-y.

Gharetepeh, A., Safari, Y., Pashaei, T., Razaei, M., \& Bagher Kajbaf, M. (2015). Emotional intelligence as a predictor of self-efficacy among students with different levels of academic achievement at Kermanshah University of Medical Sciences. Journal of advances in medical education \& professionalism, 3(2), 50-55.

Fakhr Eldn, H. (2017). The relationship between the emotional intelligence of entrepreneurs and the new venture creation: The role of age, gender and motive. Arab Economic and Business Journal. https://doi.org/10.1016/j.aebj.2017.10.002.

Khan, Mahmood \& Lone, Mohammad Muzzafar. (2015). Emotional Intelligence of Rural and Urban Post Graduate Students of Kashmir University. III. 181-184.

Mayer, J, \& Salovey, P. (1993). Emotional intelligence: new abilty or eclictic traits. American Psychologist. 63(6), 503. PMid: 18793038. https://doi.org/10.1037/0003-066X.63.6.503 .

Mayer, J. D. \& Salovey, P. (1997). emotional development and emotional intelligence: Educational Implications. 3-31.

Mikolajczak, M., Luminet, O., \& Menil, C. (2006). Predicting resistance to stress: Incremental validity of emotional intelligence over and above alexithymia and optimism. Psicothema, 18, 79-88.

Nicola S. Schutte, John M. Malouff, Maureen Simunek, Jamie McKenley \& Sharon Hollander (2002) Characteristic emotional intelligence and emotional well-being, Cognition and Emotion, 16:6, 769-785, DOI: 10.1080/02699930143000482

Pearlman, K., \& Barney, M. F. Final Draft--December 28, 1998.

Petrides, K. V., Pita, R., \& Kokkinaki, F. (2007). The location of trait emotional intelligence in personality factor space. British Journal of Psychology, 98, 273-289. PMid: 17456273. https://doi.org/10.1348/000712606X120618.

Petrides, K. V. (2007). Psychometric properties of the Trait Emotional Intelligence Questionnaire. (TEIQue). In Assessing emotional intelligence (pp. 85-101). Springer, Boston, MA.

Pooja, P., \& Pranab, K. (2016). Demographic variables and its effect on emotional intelligence: A study on indian service sector employees. Annals of Neurosciences. 23. 18-24. PMid: 27536018 PMCid: PMC4934457. https://doi. org/10.1159/000443552 .

Ramesar, S., Koortzen, P., \& Oosthuizen, R. M. (2009). The relationship between emotional intelligence and stress management. SA Journal of Industrial Psychology/SA 
TydskrifvirBedryfsielkunde, 35(1). https://doi.org/10.4102/ sajip.v35i1.443.

Singh, R., Pant, K., \& Laitonjam, V. (2014).) Impact analysis: Family structure on social and emotional maturity of adolescents. Anthropologist. 17, 359-365. https://doi.org/10.10 80/09720073.2014.11891445.
Sony, M., \& Mekoth, N. (2016). The relationship between emotional intelligence, frontline employee adaptability, job satisfaction and job performance. Journal of Retailing and Consumer Services. 30:20-32. https://doi.org/10.1016/j.jretconser.2015.12.003 